Arkivoc

Free to Authors and Readers
A Platinum Open Access Journal for Organic Chemistry

Paper

DOAJ Seal
Arkivoc 2021, part viii, 23-37

\title{
Synthesis and DFT studies of novel aminoimidazodipyridines using 2-(3H- imidazo[4,5-b]pyrid-2-yl)acetonitrile as an efficient key precursor
}

\author{
Ahmed F. Darweesh, ${ }^{a}$ Nesma A. Abd El-Fatah, ${ }^{a}$ Samir A. Abdel-Latif, ${ }^{b}$ Ismail A. Abdelhamid, ${ }^{a *}$ Ahmed H. M. \\ Elwahy $^{a *}$ and Mostafa E. Salem ${ }^{a}$ \\ ${ }^{a}$ Department of Chemistry, Faculty of Science, Cairo University, Giza 12613, Egypt \\ ${ }^{b}$ Department of Chemistry, Faculty of Science, Helwan University, Cairo 11795, Egypt \\ Email: ismailshafy@yahoo.com, aelwahy@hotmail.com
}

Received 11-10-2020

Accepted 01-20-2021

Published on line $\quad 02-08-2021$

\section{Abstract}

Novel 9-aminoimidazo[1,2-a:5,4- $b^{\prime}$ ]dipyridine-6,8-dicarbonitriles were prepared via the Michael addition reaction of readily accessible 2-(3H-imidazo[4,5-b]pyrid-2-yl)acetonitrile with arylidenemalononitriles. The regioselectivity of the reaction was supported by theoretical calculations at the DFT level. In contrast, the reaction of the appropriate bis-arylidenemalononitrile with 2-(3H-imidazo[4,5-b]pyrid-2-yl)acetonitrile under similar reaction conditions gave the corresponding bis[2-(3H-imidazo[4,5-b]pyrid-2-yl)acrylonitriles].

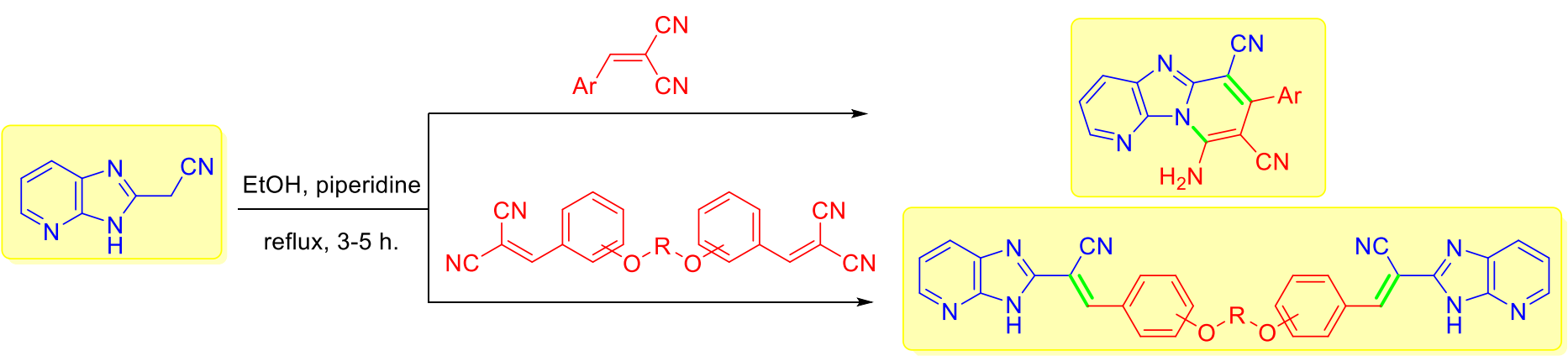

Keywords: $\quad$ 2-(3H-imidazo[4,5-b]pyrid-2-yl)acetonitrile, $\quad$ 9-aminoimidazo[1,2-a:5,4- $b$ ']dipyridine-6,8dicarbonitrile, arylidenemalononitriles, bis[2-(3H-imidazo[4,5-b]pyrid-2-yl)acrylonitriles], DFT studies. 


\section{Introduction}

Imidazo[4,5-b]pyridines are important classes of heterocyclic compounds that possess diverse pharmacological properties including anticancer, ${ }^{1}$ antimicrobial, ${ }^{2}$ anti-inflammatory, ${ }^{3}$ and antiviral activities..$^{4,5}$ Moreover, $\mathrm{N}$-fused polyheterocycles display also a wide range of biological activities. ${ }^{6}$ In particular, imidazo[1,2-a:5,4- $\left.b^{\prime}\right]$ dipyridines exhibit interesting anticancer ${ }^{7}$ and antiviral ${ }^{8}$ activities. Some examples of biologically active compounds containing an imidazo[1,2-a:5,4-b']dipyridine such as (CF02334) 1 , a selective inhibitor of the cytopathic effect (CPE) caused by bovine viral diarrhea ${ }^{8}$ and anti-human prostate cancer $\mathbf{2}^{7}$ are outlined in Figure 1. In addition, the development of simple and efficient synthetic routes to novel heterocyclic compounds represents a great challenge in organic synthesis. In this respect, the Michael addition reaction has attracted much attention in the last decades as an effective strategy for the synthesis of heterocycles and their fused derivatives under mild reaction conditions. ${ }^{9,10}$ Moreover, due to their promising nonlinearoptical (NLO) properties, imidazo[1,2-a]pyridine and their corresponding fused derivatives have a diverse range of applications in material chemistry. In this respect, many of these derivatives have been used as multiple fluorescent chemosensors, in an electron transport layer of an organic light emitting device, as biomarkers of hypoxic tumor cells, and as a receptor in fluorescent high-affinity ligand in dopamine D3. ${ }^{11-14}$

In connection with the increasing interest of adoption of new synthetic methods in drug discovery, and in continuation to our recent applications of carbon-Michael ${ }^{15-18}$ as well as aza-Michael ${ }^{16}$ addition reactions as powerful tools for the synthesis of nitrogen containing heterocycles and their corresponding bisheterocycles, ${ }^{15,17,19-26}$ we report herein our investigation on the reactivity of 2-(3H-imidazo[4,5-b]pyrid-2yl)acetonitrile towards arylidenemalononitriles and bis-arylidenemalononitriles aiming at synthesizing novel mono- and bis-imidazo[1,2-a:5,4- $b$ ']dipyridine-6,8-dicarbonitriles. In addition, a theoretical density functional theory (DFT) study aims to determine the more stable regioisomer of the two possible expected isomeric products from the mentioned reactions as well as to investigate the efficacy of the target compounds as suitable candidate for NLO material.

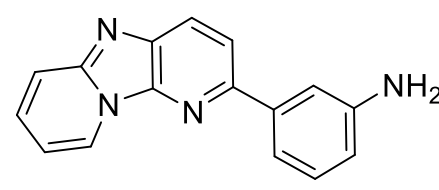

1

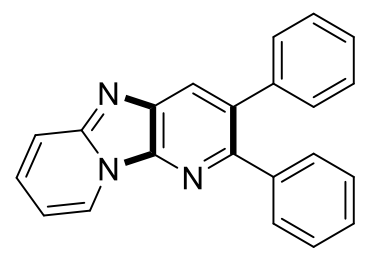

2

Figure 1. Some examples of biologically active compounds containing imidazo[1,2-a:5,4-b']dipyridines.

\section{Results and Discussion}

\section{Synthesis}

Previously, various methods have been reported for the synthesis of imidazo[1,2-a:5,4- $b$ ']dipyridines. Most of these methods depend mainly on the formation of 3-aminoimidazo[1,2-a]pyridines followed by their reaction with the appropriate reagents. In this respect, Takeda et al. ${ }^{27}$ synthesized imidazodipyridines 5 by the reaction of 3-aminoimidazo[1,2-a]pyridine $3(R=H)$ with 2-chloroacrylonitrile 4 in nitrobenzene in the presence of 
$\mathrm{AlCl}_{3}$. Moreover, Desbois et $a .^{28}$ synthesized imidazo[1,2-a:5,4- $\left.b^{\prime}\right]$ dipyridines 6 via the reaction of 3-amino-2formylimidazo[1,2-a]pyridine $3(\mathrm{R}=\mathrm{CHO})$ with various aldehydes or ketones by Friedländer's method (Scheme 1).

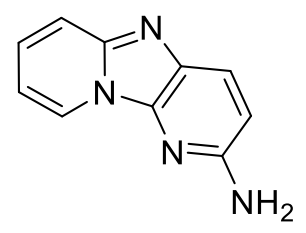

5

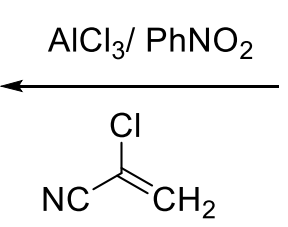

4

$\mathrm{R}=\mathrm{H}$

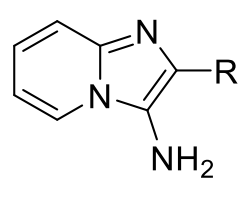

3

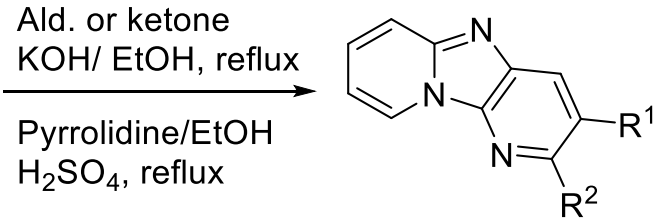

6

$\mathrm{R}=\mathrm{CHO}$

Scheme 1. Reported Methods for the synthesis of imidazodipyridines $\mathbf{5}$ and $\mathbf{6}$.

Li et $a .^{7}$ and Zhang et al. ${ }^{29}$ also reported on the utility of some imidazo[1,2-a]pyridin-3-amines as precursors for the synthesis of imidazo[1,2-a:5,4- $\left.b^{\prime}\right]$ dipyridines.

In searching for an expedient strategy for synthesis of imidazodipyridines, our attention focused on $2-(3 \mathrm{H}-$ imidazo[4,5-b]pyrid-2-yl)acetonitrile (10) as a precursor. Compound 10 was prepared via the solvent-free reaction of pyridine-2,3-diamine (7) with ethyl cyanoacetate (8) in an oil bath at $180-190{ }^{\circ} \mathrm{C}$ for 30 minutes (Scheme 2). The structure of compound 10 was supported by the presence of FTIR bands at 3410 and $2252 \mathrm{~cm}^{-}$ ${ }^{1}$ characteristic for $v(\mathrm{~N}-\mathrm{H})$ and $v(\mathrm{C} \equiv \mathrm{N})$ groups, respectively. The ${ }^{1} \mathrm{H} N M R$ spectrum of compound 10 reveals the methylene group and the $\mathrm{NH}$ protons at $\delta 4.42$ and 13.18 , respectively. The data agreed with that previously reported for compound $\mathbf{1 0 . 3 0 , 3 1}$

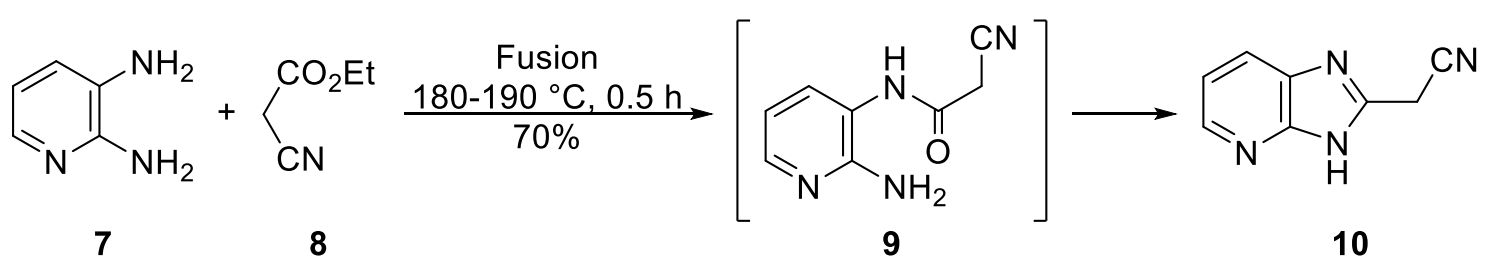

Scheme 2. Synthesis of 2-(3H-imidazo[4,5-b]pyrid-2-yl)acetonitrile 10.

The reactivity of compound $\mathbf{1 0}$ towards substituted cinnamonitriles was then investigated. Compound $\mathbf{1 0}$ (a Michael donor) has two nucleophilic centers ( $\mathrm{NH}$ group and $\mathrm{CH}_{2}$ ) at which the Michael addition to the Michael acceptor 11 can initiate. Thus, two regioisomeric products are possible by the reaction of compound 10 with the activated double bond reagents 11 via routes $A$ and $B$ (Schemes $3 \& 4$ ). Route $A$ involves the initial nucleophilic addition of $\mathrm{CH}_{2}$ of compound $\mathbf{1 0}$ to $\beta$-carbon of the activated double bond of 11 followed by cyclization that involves the $\mathrm{NH}$ group to afford 9-amino-7-arylimidazo[1,2- $a: 5,4-b^{\prime}$ ] dipyridine-6,8dicarbonitrile 12 through intermediates 14 and 15 (Scheme 4). Route B encompasses the initial addition of the $\mathrm{NH}$ group of the compound $\mathbf{1 0}$ to the activated double bond of $\mathbf{1 1}$ followed by cyclization involving $\mathrm{CH}_{2}$ of $\mathbf{1 0}$ to give 7-amino-9-arylimidazo[1,2-a:5,4- $b^{\prime}$ ]dipyridine-6,8-dicarbonitrile 13 through intermediates 16 and 17 (Scheme 4). The structures of the expected products 12 or 13 could not be determined based on spectral analyses as both of them give similar data. For example, the IR spectrum of the compound produced from the reaction of 10 with 11a showed the presence of amino group at $v(\mathrm{~N}-\mathrm{H}) 3456$ and $3317 \mathrm{~cm}^{-1}$ as well as characteristic nitrile band at $v(\mathrm{C} \equiv \mathrm{N}) 2214 \mathrm{~cm}^{-1}$. Its ${ }^{1} \mathrm{H}$ NMR spectrum revealed the amino group at $\delta 8.89$ as a broad signal. Unfortunately, these data can agree with both structures 12 and 13. 


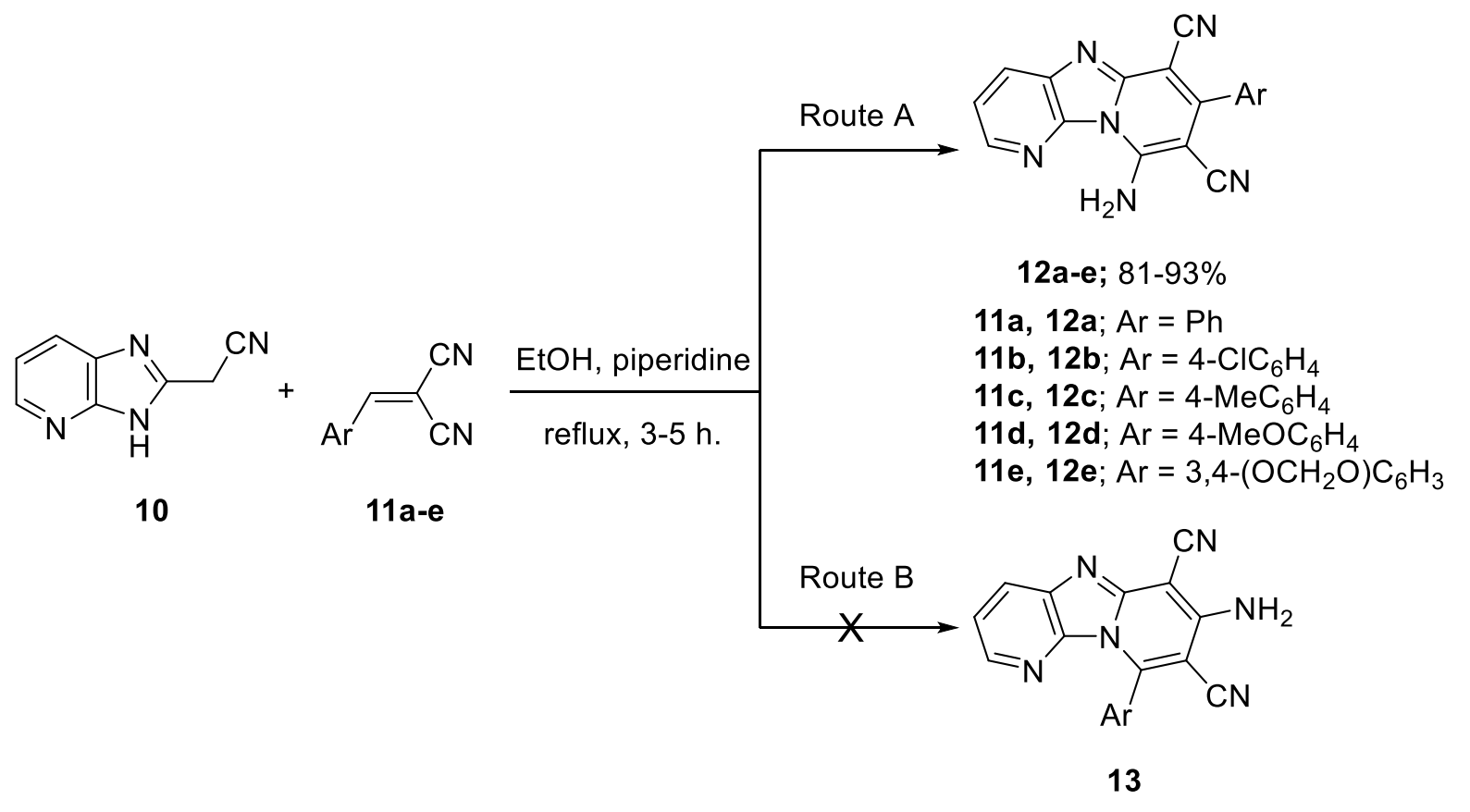

Scheme 3. Synthesis of compounds 6a-e via reaction of $\mathbf{4}$ with cinnamonitriles.<smiles>N#CC(C#N)=CCCC(C#N)c1nc2cccnc2[nH]1</smiles>

11
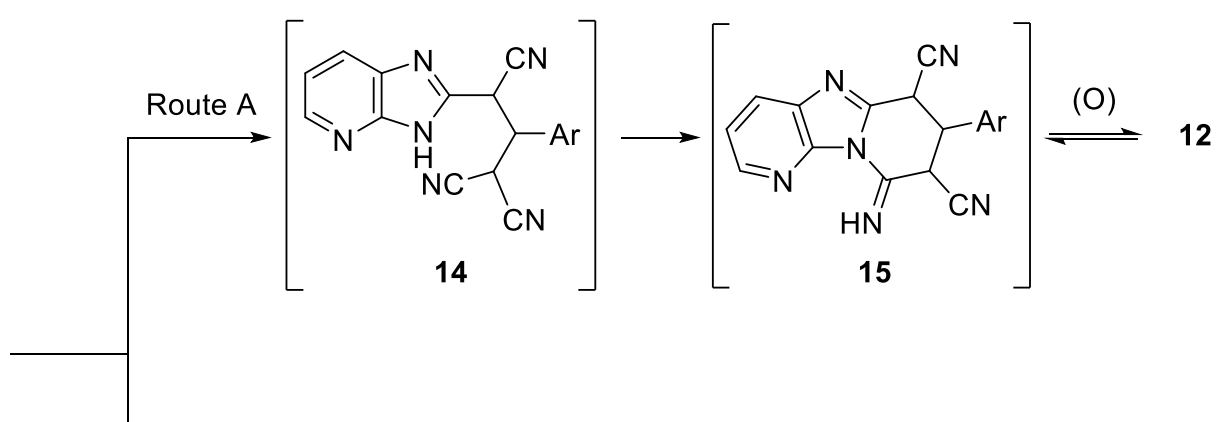

Route B<smiles>N#CCc1nc2cccnc2n1C([Al])C([Al])C#N</smiles>

(O) $\rightleftharpoons 13$

Scheme 4. Expected routes (A and B) for the formation of regioisomeric products 12 and 13.

Route A that affords compounds $\mathbf{1 2}$ was approved based on literature similarities ${ }^{32,33}$ that indicated the superiority of the nucleophilicity of $\mathrm{CH}_{2}$ over $\mathrm{NH}$ group. Further support for the formation of compound 12a was provided by an alternative synthesis via a three component reaction of 2-(3H-imidazo[4,5-b]pyrid-2$\mathrm{yl}$ )acetonitrile 10 with both benzaldehyde (18) and malononitrile (19) in EtOH heated at reflux in the presence of catalytic piperidine (Scheme 6, Method B). Moreover, compound 12a was also obtained via the reaction of malononitrile (19) with a preheated mixture of benzaldehyde (18) and 2-(3H-imidazo[4,5-b]pyrid-2$\mathrm{yl})$ acetonitrile 10. In support of this viewpoint, we also isolated the Knoevenagel condensation product $2-(3 \mathrm{H}$ imidazo[4,5-b]pyrid-2-yl)-3-phenylacrylonitrile (20) (Scheme 5, method C). The formation of 12a from the 
reaction of 20 with 19, with identical physical and spectral data with that prepared from the reaction of 10 and 11a, supports the reaction proceeded via route $A$ and not via route $B$.
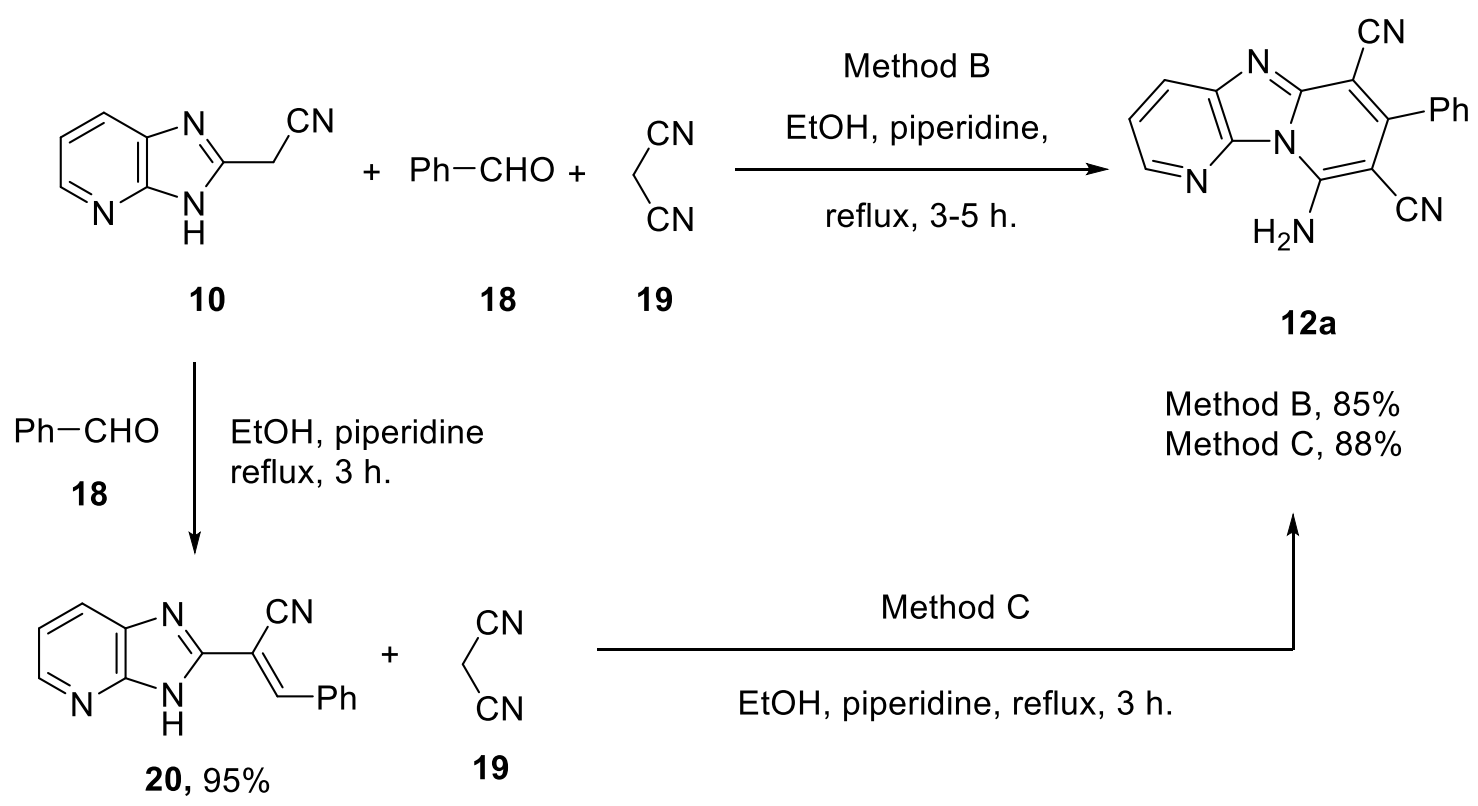

Scheme 5. Alternative methods for the synthesis of compound 12a.

The regioselective formation of $\mathbf{1 2}$ was also supported by theoretical calculations at DFT level (cf. Molecular orbital calculations).

In searching for the optimal reaction conditions, the reaction was carried out in different solvents as well as in the presence of a variety of bases. Firstly, we tried $\mathrm{EtOH}$ as a solvent and DABCO, pyridine, $\mathrm{KOH}, \mathrm{TEA}$ and piperidine as bases. Among the different bases, the use of piperidine gave the cleanest products and best yields. The reaction was also examined in different solvents including dioxane, dichloromethane, acetonitrile, water and DMF heated at reflux in each case. The reaction proceeded in most solvents but with different degrees of conversion; EtOH was the best solvent in terms of reaction time and yield. The reactions were completed in 3-5 h, while prolonged heating did not improve the reaction yield. On the other hand, no traces of products were obtained at room temperature. The reactivity of compound $\mathbf{1 0}$ towards heteromethylenemalononitriles was also investigated aiming at synthesizing novel imidazo[1,2-a:5,4$b^{\prime}$ ]dipyridines which are linked to heterocyclic moieties at position 7. Thus reaction of 10 with each of 2-[(1,3diphenylpyrazol-4-yl)methylene]malononitrile (21a) and 2-\{[1-phenyl-3-(thien-2-yl)-pyrazol-4-yl]methylene\}malononitrile (21b) afforded 9-amino-7-arylimidazo[1,2-a:5,4- $b$ ']dipyridine-6,8-dicarbonitrile 22a and 22b, respectively, in good yields (Scheme 6). 


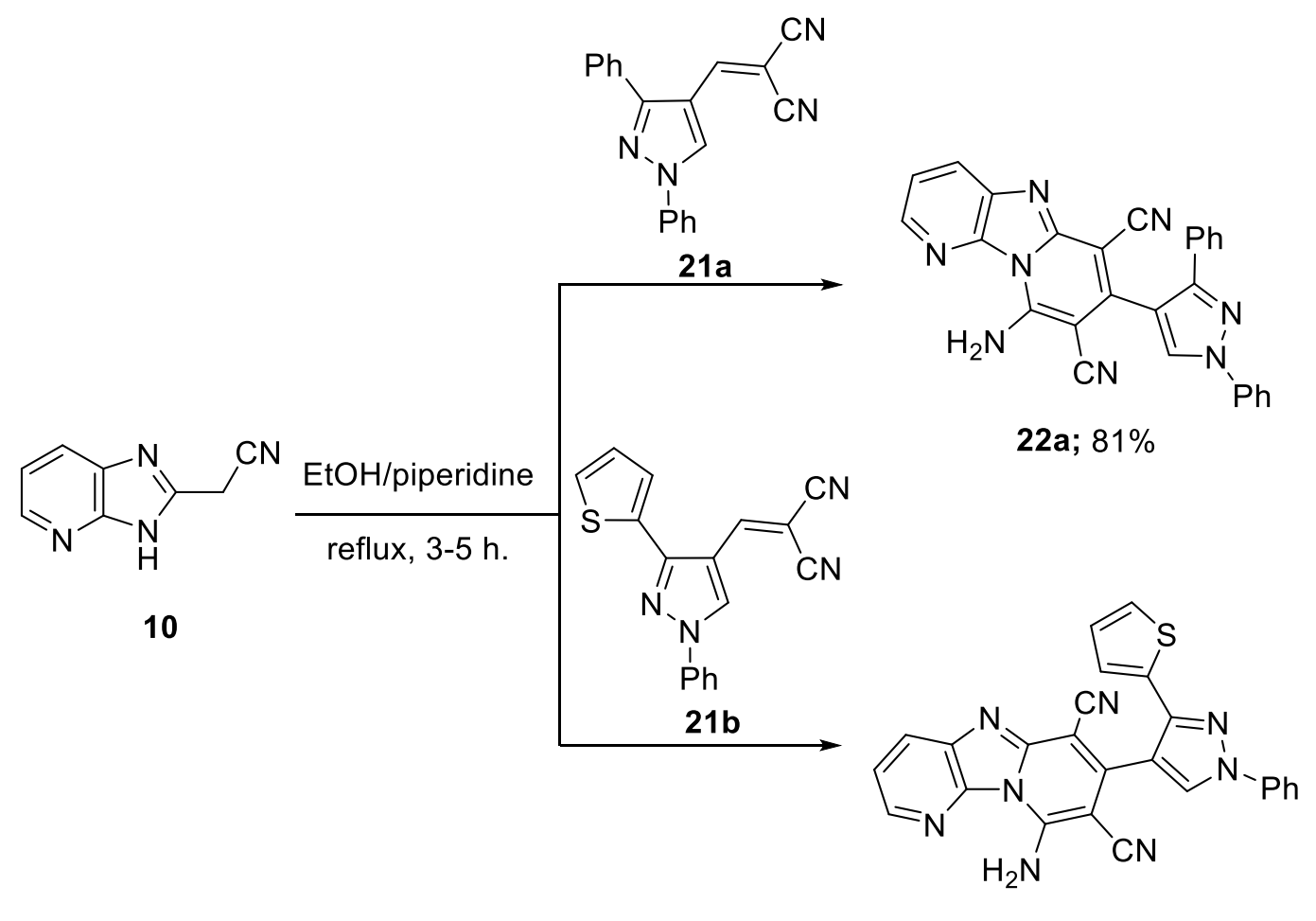

22b; $71 \%$

Scheme 6. Synthesis of imidazo[1,2-a:5,4- $\left.b^{\prime}\right]$ dipyridines $22 a$ and $22 b$ via reaction of compound 10 with heteromethylenemalononitriles.

Our study was extended to investigate the reactivity of 2-(3H-imidazo[4,5-b]pyrid-2-yl)acetonitrile (10) towards bis-arylidenemalononitrile 23 in a trial to prepare bis-9-amino-7-arylimidazo[1,2-a:5,4- $b^{\prime}$ ]dipyridine-6,8dicarbonitriles 24. Unfortunately, Michael addition of two equivalents of 2-(3H-imidazo[4,5-b]pyrid-2$\mathrm{yl}$ )acetonitrile $(\mathbf{1 0})$ to bis-arylidenemalononitriles did not lead to the formation of $\mathbf{2 4}$. Instead the reaction gave bis[2-(3H-imidazo[4,5-b]pyrid-2-yl)acrylonitriles] 25a-d (Scheme 7). Compounds 25 are assumed to form via the initial formation of the Michael adducts $\mathbf{2 6}$ which then decompose to afford $\mathbf{2 5}$ via elimination of malononitrile (Scheme 8). A similar pathway has been reported. ${ }^{34}$ The structures of compounds $\mathbf{2 5 a - d}$ were supported by comparison of their physical data with authentic samples prepared from the reaction of one equivalent of bisaldehydes 27 with two equivalents of 2-(3H-imidazo[4,5-b]pyrid-2-yl)acetonitrile (10) in EtOH in the presence of catalytic piperidine (Scheme 9). The constitutions of compounds $\mathbf{2 5}$ were established based on spectral data. Thus, the ${ }^{1} \mathrm{H}$ NMR spectrum of compound 25a as a representative example revealed two singlet signals at $\delta 4.63$ and 8.59 for the $\mathrm{OCH}_{2}$ groups and the ylidene $\mathrm{H}$-atoms, respectively. Moreover, it revealed the $\mathrm{NH}$ group as broad singlet at $13.63 \mathrm{ppm}$. 


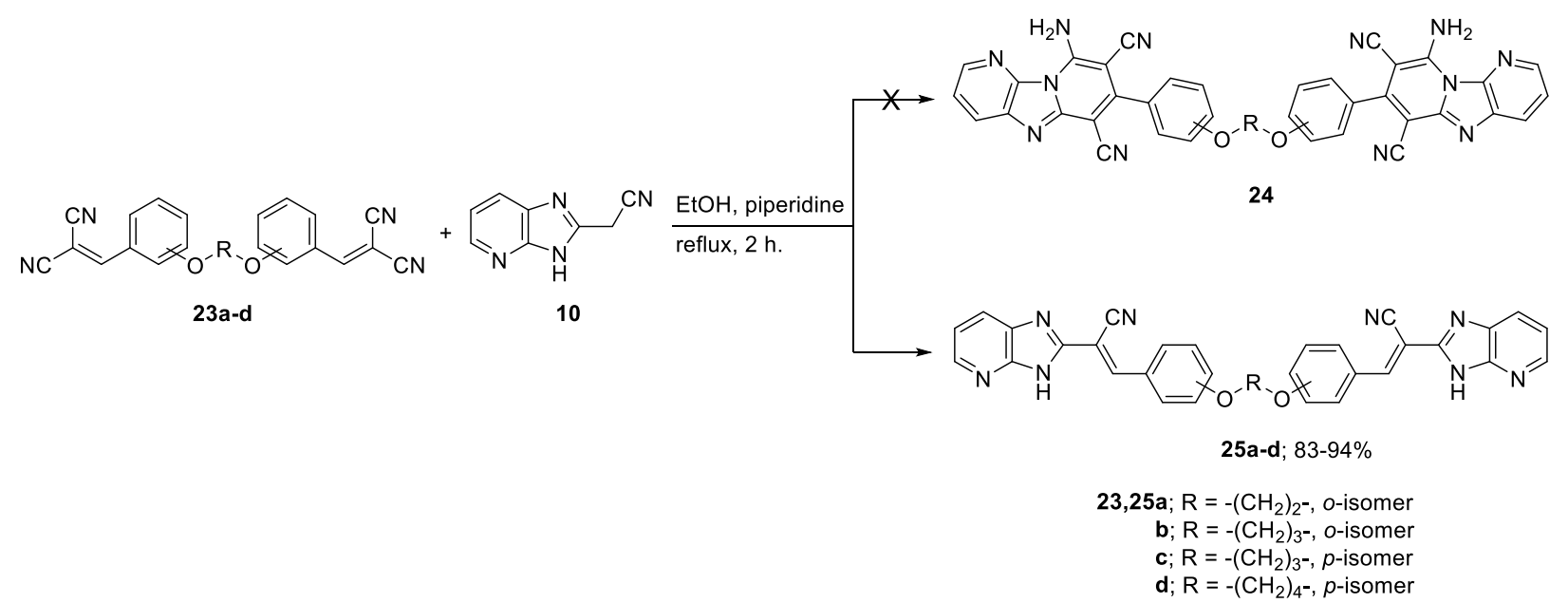

Scheme 7. Attempted synthesis of bis-9-amino-7-arylimidazo[1,2- $a: 5,4-b^{\prime}$ ]dipyridine-6,8-dicarbonitriles 24 via reaction of $\mathbf{1 0}$ with bis-arylidenemalononitrile 23 .

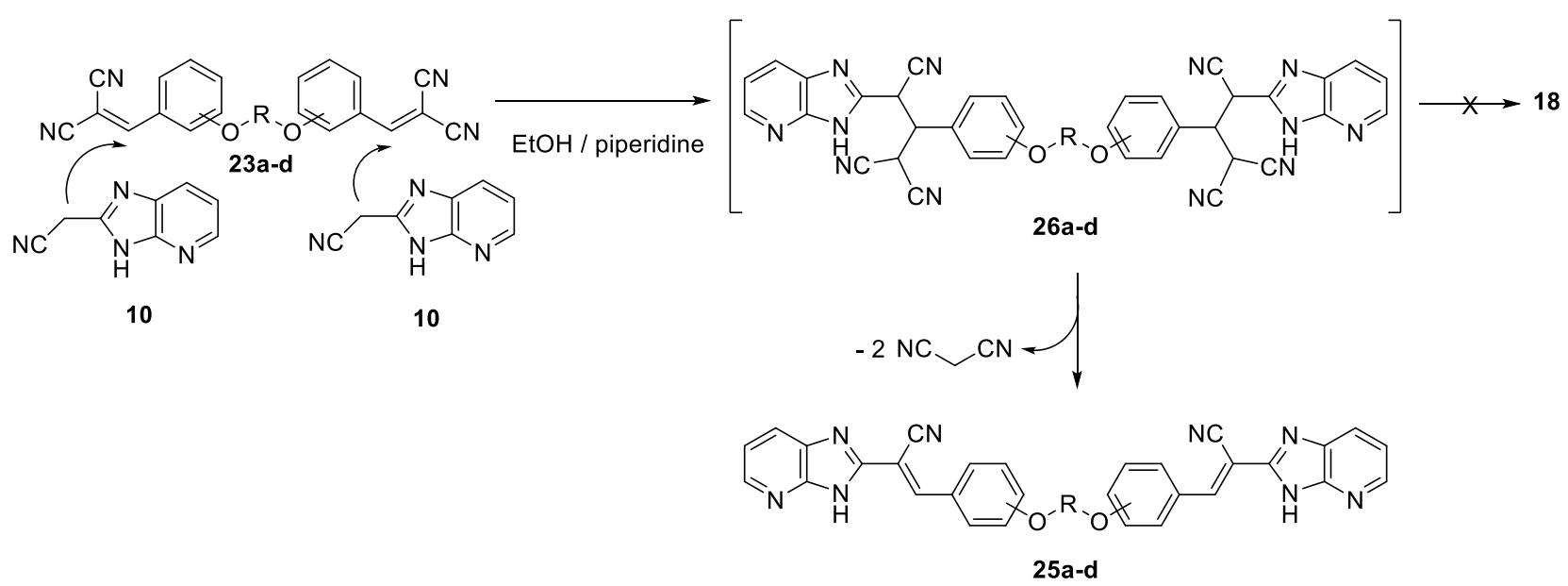

Scheme 8. Plausible mechanism for the formation of $\mathbf{2 5 a - d}$ via reaction of $\mathbf{1 0}$ with bis-arylidenemalononitrile 23.

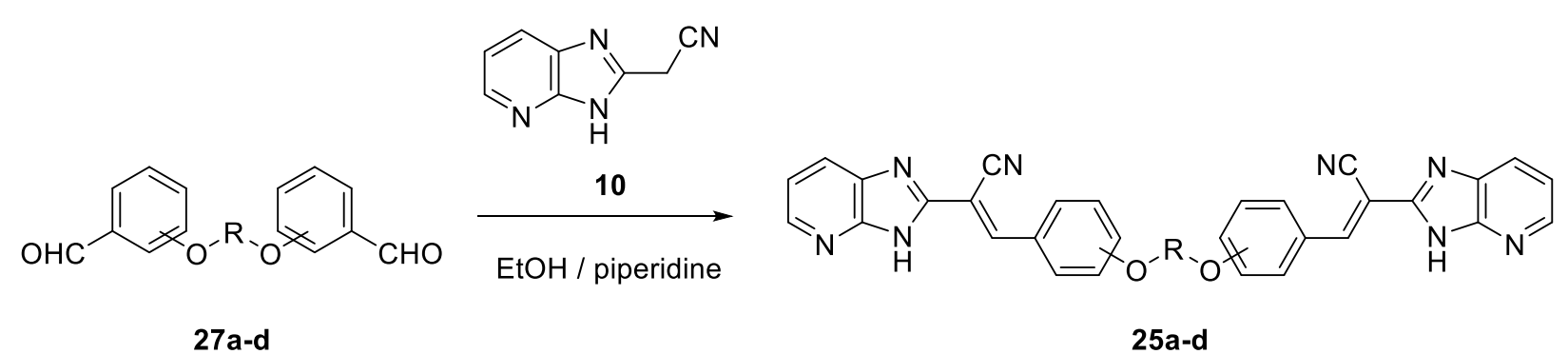

Scheme 9. Synthesis of compounds $\mathbf{2 5 a - d}$ by the reaction of one equivalent of bis-aldehydes $\mathbf{2 7}$ with two equivalents of 10 . 
Theoretical calculations

\section{Geometry of compounds 12 and 13}

Geometry structures of the expected products 12 and 13 and their intermediates 14 and 16 were optimized at the B3LYP/6-311G** level and the results are given in Table 1. The reaction of 10 with 11 can lead to the formation of the regioisomer 12, via intermediate 14 through the attack of the active $\mathrm{CH}_{2}$ of 10 (C14) on $\mathrm{CH}$ groups of 11 (C12). On the other hand, the regioisomer 13 can arise via initial attack of NH of 10 on $\mathrm{CH}$ of 11 to give intermediate 16 as seen in Fig. 2 (cf. supporting information). The energy of regioisomer 13 was 7.15 $\mathrm{kcal} / \mathrm{mol}$ higher than that of 12, i.e., the structure of 12 was more stable. Also, the intermediate 16 has energy of $5.52 \mathrm{kcal} / \mathrm{mol}$ higher than that of $\mathbf{1 4}$. Therefore, this study supports the regioselective formation of $12 \mathrm{from}$ the reaction of $\mathbf{1 0}$ with $\mathbf{1 1}$. The planarity of $\mathbf{1 2}$ can be estimated from the values of the dihedral angles. Compound 12 has a non-planar structure where the phenyl ring rotates out of the plane. This is can be indicated from the dihedral angles of the phenyl ring attached to C13-C24, especially the angles $(<\mathrm{C} 13-\mathrm{C} 11-$ C12-N17), (<C13-C14-C16-N18) and (<C11-C13-C24-C29) which are $-176.879^{\circ},-179.389^{\circ}$ and $123.976^{\circ}$ (Table 1 , cf. supporting information). Where these angles are far from $0^{\circ}$ or $180^{\circ}$. This also can be verified from the bond angel (<C14-C13-C24) which has the value of $119.117^{\circ}$ (Table 1$)$.

\section{Ground state properties and Global reactivity descriptors}

The energy difference between the HOMO and LUMO, $E_{\mathrm{g}}$, of compounds 10, 11 and 12 occur in the range 5.28-3.32 eV. The energy gap of compound $\mathbf{1 0}$ is the maximum $(5.28 \mathrm{eV})$ while that for compound 12 has the minimum $(3.32 \mathrm{eV})$ value (Table 2). As a result, charge transfer and polarization can easily occur with more reactivity within 12 than 10 and $\mathbf{1 1}$. The electronegativity, $\chi$, chemical hardness, $\eta$, global softness, $S$, chemical potential, $\pi$, were calculated using HOMO and LUMO energies and were recorded in Table 2, Fig. 3 (cf. supporting information). Compound 10 has the lowest $\eta$ and maximum $S$ value which means that the charge transfer occurs easily in this compound and it has a lower chemical hardness. Large $E_{\mathrm{g}}$ gaps are representative of the hardness of the molecule, while smaller $E_{\mathrm{g}}$ gaps are representative for soft and reactive molecules. The accumulated data in Table 2 showed that the HOMO of 12 is less stable than that of the other compounds and has lower IP value. The electron affinities values are of the order: $10<12<11$. The processed reactivity parameters are shown in Table 2 which revealed that compound 10 has the lowest $\eta$ and minimum $S$ values. This indicated that it has lower chemical hardness. The 3-D distribution of frontier MOs, HOMO and LUMO of 10, 11 and 12 are presented in Fig. 2. The calculated values of $E_{\mathrm{HOMO}}$ and $E_{\mathrm{LUMO}}$ of 12 are -6.1690 and $-2.8478 \mathrm{eV}$, respectively, thus the energy gap value $E_{\mathrm{g}}$ is $3.3212 \mathrm{eV}$. It can be regarded from Fig. 3 that the HOMO and LUMO of 12 are mainly allocated over the whole molecule. The partial frontier molecular orbital compositions and the energy levels of $\mathbf{1 2}$ in the ground state are recorded in Table 2 and Fig. 3.

Table 2. Total energy, energy of HOMO and LUMO, energy gap, of 10, 11, 12, 13, 14 and 16 usingB3LYP/6$311 \mathrm{G} * *$

\begin{tabular}{ccccccc}
\hline Parameter & $\mathbf{1 0}$ & $\mathbf{1 1}$ & $\mathbf{1 2}$ & $\mathbf{1 3}$ & $\mathbf{1 4}$ & $\mathbf{1 6}$ \\
\hline$E_{\mathrm{T}}, \mathrm{eV}$ & -14350 & -13436 & -27762 & -27744 & -27771 & -27771 \\
$E_{\text {номо }}, \mathrm{eV}$ & -6.7891 & -7.3929 & -6.1690 & -5.9867 & -6.8653 & -6.9795 \\
$E_{\text {LUMO }}, \mathrm{eV}$ & -1.5150 & -3.0926 & -2.8478 & -3.2776 & -1.7789 & -1.8170 \\
$E_{\mathrm{g}} \mathrm{eV}$ & 5.2741 & 4.3003 & 3.3212 & 2.7091 & 5.0864 & 5.1625 \\
\hline
\end{tabular}


The frequency calculations for compound 12a (Figure 4, cf. supporting information) were performed using B3LYP/6-31G(d,p). The data obtained are comparable with that theoretically calculated (Exp. 3456, 3317, 2214; Calc. 3470, 3240, $2212 \mathrm{~cm}^{-1}$ ) cf. experimental section. TD-DFT calculations for compound 12a (Figure 5, cf. supporting information) were brought out at the same level of theory [B3LYP/6-31G(d,p)] to clarify the origin of the electronic spectra, using the polarizable continuum solvation method, PCM, PCM-TD-DFT. The theoretical spectrum of 12a is characterized by five bands at 361 (3.4316 eV), 308 (4.0224 eV), 286 (4.3248 eV), 262 (4.7280 eV) and $245 \mathrm{~nm}$ (5.0405 eV). Theoretical IR and UV spectra of 12a using B3LYP6-31G(d,p) are mentioned in supplementary material.

\section{Non-linear optical properties (NLO)}

The circulation of the atomic charges in the chelates is also valuable in the determination of the magnitude and direction of the moment vector which depends on the centers of negative and positive charges. The dipole moment, the mean polarizability, the anisotropy of the polarizability and the first-order hyperpolarizability for compounds 10,11 and 12 were calculated using the same level and the obtained values are tabulated in Table 3. The table also includes the experimental values of urea. The considered dipole moment values of 10,11 and 12 in the gas phase are 4.4076, 6.6808 and 5.3942 D, respectively. The analyzed values of the polarizability of 10,11 and 12 have the range $1.09-7.02 \times 10^{-24}$ (esu). Compound 11 has the lowest calculated value and 12 has $7.02 \times 10^{-24}$. Compared with urea ${ }^{35}$ as a reference substance, all the studied chelates have higher polarizability and first-order hyperpolarizability. The polarizabilities and first-order hyperpolarizabilities are reported in atomic units (a.u.), the calculated values have been changed into electrostatic units (esu) using conversion factor of $0.1482 \times 10^{-24}$ esu for $\alpha$ and $8.6393 \times 10^{-33}$ esu for $\beta$. Urea is used as standard example in non-linear optical studies. In this study, urea is chosen as a reference material as there were no experimental values of NLO properties for the new derivatives. The extent of the molecular hyperpolarizability $(\langle\beta>)$ is one of the key factors in non-linear optical system. The calculated $(<\beta>)$ values for compounds 10, 11 and 12 are $\sim 6, \sim 60$, and $\sim 6$, times greater than that of urea, respectively. Therefore, all the studied compounds reveal considerable polarizability and first-order hyperpolarizability and are projected to be successful encouraged for NLO materials.

\section{Conclusions}

We developed a simple and an efficient method for the preparation of novel 9-aminoimidazo[1,2-a:5,4$b^{\prime}$ ]dipyridine-6,8-dicarbonitriles via the Michael addition reaction that involves 2-(3H-Imidazo[4,5- $\left.b\right]$ pyrid-2$\mathrm{yl}$ )acetonitrile (as Michael donor) and the appropriate arylidenemalononitriles (as Michael acceptor). Also, we managed to synthesize bis[2-(3H-imidazo[4,5-b]pyrid-2-yl)acrylonitriles] through the reaction of 2 - $(3 \mathrm{H}$ imidazo[4,5-b] pyrid-2-yl)acetonitrile with bis-arylidenemalononitriles under similar reaction conditions. The theoretical calculations were carried out using Gaussian 09 W package with Gauss View 5. The analysis includes bond lengths, bond angles, molecular electrostatic potential maps, description of the important frontier molecular orbital surfaces of the compounds. The optimized molecular structure of the compounds was obtained at B3LYP/6-311G**. The regioisomer 13 has higher energy than that of $\mathbf{1 2}$. This gives further confirmation for the formation of the more stable regioisomer 12 . The polarizability and hyperpolarizabilities parameters of the compounds indicated that they are suitable candidate for NLO material. 


\section{Experimental Section}

General. Melting points were determined in open glass capillaries with a Gallenkamp apparatus. The infrared spectra were recorded in potassium bromide disks on a Pye Unicam SP 3-300 and Shimaduz FTIR 8101 PC infrared spectrophotometer. NMR spectra were recorded using a Varian Mercury VXR-300 NMR spectrometer or Bruker Ultrashield $400 \mathrm{MHz}$ or Ascend $400 \mathrm{MHz}\left({ }^{1} \mathrm{H}: 300\right.$ or $400 \mathrm{MHz},{ }^{13} \mathrm{C}: 75$ or $\left.100.6 \mathrm{MHz}\right)$ instruments using DMSO- $d_{6}$ as solvent. Mass spectra (EI) were obtained at $70 \mathrm{eV}$ using a type Shimadzu GCMQP 1000 EX Spectrometer. Elemental analyses were performed on a Perkin-Elmer 240 microanalyser at the Micro analytical Center of Cairo University. Compounds $10^{36}, \mathbf{1 1}^{37}, \mathbf{2 3 a - d ^ { 3 8 }}$ and $\mathbf{2 7 a - d ^ { 3 8 }}$ were prepared according to the literature.

\section{General procedure for the synthesis of 9-amino-7-substituted imidazo[1,2-a:5,4- $b$ ']dipyridine-6,8-} dicarbonitrile 12a-e and 22a,b

Method A. To a mixture of appropriate arylidene malononitrile 11a-e, 21a or $21 \mathbf{b}(1 \mathrm{mmol})$ and $2-(3 \mathrm{H}-$ imidazo[4,5-b]pyrid-2-yl)acetonitrile (10) $(1 \mathrm{mmol}, 158 \mathrm{mg})$ in absolute EtOH $(15 \mathrm{~mL})$ was added piperidine (1 $\mathrm{mmol}, 110 \mu \mathrm{L}$ ), and the mixture was heated at reflux for 3-5 $\mathrm{h}$. The crude solid was isolated and recrystallized from EtOH/DMF to give 12a-e and 22a,b, respectively.

\section{For compound 12a:}

Method B. To a mixture of benzaldehyde (18) (1 mmol, $106 \mathrm{mg})$, malononitrile (19) (1 mmol, $66 \mathrm{mg})$ and 2(3H-imidazo[4,5-b]pyrid-2-yl)acetonitrile (10) (1 mmol, $158 \mathrm{mg}$ ) in absolute $\mathrm{EtOH}(25 \mathrm{~mL})$ was added piperidine $(1 \mathrm{mmol}, 110 \mu \mathrm{L})$, and the reaction mixture was heated at reflux for $5 \mathrm{~h}$. The crude solid was isolated and recrystallized from DMF/EtOH (25:75) to give 12a.

Method C. A mixture of 2-(3H-imidazo[4,5-b]pyrid-2-yl)-3-phenylacrylonitrile (20) (1 mmol, $246 \mathrm{mg})$ and malononitrile (19) (1 mmol, $66 \mathrm{mg})$ in absolute EtOH $(15 \mathrm{~mL})$ was added piperidine (1 mmol, $110 \mu \mathrm{L})$, and the mixture was heated at reflux for $3 \mathrm{~h}$. The crude solid was isolated and recrystallized from DMF/EtOH (25:75) to give $12 \mathrm{a}$.

9-Amino-7-phenylimidazo[1,2-a:5,4-b']dipyridine-6,8-dicarbonitrile (12a). Brown crystals, (method A (288 $\mathrm{mg}, 93 \%)$; method B (263 mg, 85\%); method C (273 mg, 88\%); mp > $300{ }^{\circ} \mathrm{C}$; IR (KBr) v (Exp. 3456, 3317, 2214; Calc. $3470,3240,2212) \mathrm{cm}^{-1} ;{ }^{1} \mathrm{H}$ NMR $\left(400 \mathrm{MHz}\right.$, DMSO- $\left.d_{6}\right) \delta 7.42-7.46(\mathrm{~m}, 1 \mathrm{H}$, pyridine-H), 7.49-7.62 (m, 5H, ArH), 8.70-8.71 (m, $1 \mathrm{H}$, pyridine-H), 8.89 (br. s, 2H, NH 2$), 9.00-9.02$ (m, $1 \mathrm{H}$, pyridineH); ${ }^{13} \mathrm{C} \mathrm{NMR}(100 \mathrm{MHz}$, DMSO- $\left.d_{6}\right) \delta 78.7,115.9,116.2,117.2,121.8,123.6,129.2,130.7,135.2,137.8,142.1,148.4,149.7,152.8$, 154.6, 156.6; MS m/z (\%) $310\left(\mathrm{M}^{+}\right)$. Anal. Calcd for $\mathrm{C}_{18} \mathrm{H}_{10} \mathrm{~N}_{6}$ : C, 69.67; $\mathrm{H}, 3.25 ; \mathrm{N}, 27.08$. Found: $\mathrm{C}, 69.52 ; \mathrm{H}$, $3.07 ; \mathrm{N}, 26.97 \%$.

9-Amino-7-(4-chlorophenyl)imidazo[1,2-a:5,4-b']dipyridine-6,8-dicarbonitrile (12b). Brown crystals (279 mg, 81\%); $\mathrm{mp}>300{ }^{\circ} \mathrm{C} ; \mathrm{IR}(\mathrm{KBr}) \vee 3454,3317,2214 \mathrm{~cm}^{-1} ;{ }^{1} \mathrm{H}$ NMR $\left(400 \mathrm{MHz}, \mathrm{DMSO}-d_{6}\right) \delta 7.43-7.46(\mathrm{~m}, 1 \mathrm{H}$, pyridine-H), 7.64-7.72 (m, 5H, ArH), 8.69-8.71 (m, 1H, pyridine-H), 8.93 (br. s, 2H, NH $\mathrm{NH}_{2}, 9.00-9.03(\mathrm{~m}, 1 \mathrm{H}$, pyridine-H); ${ }^{13} \mathrm{C}$ NMR $(100 \mathrm{MHz}$, DMSO-d $) \delta$ 79.0, 115.9, 116.1, 117.3, 121.8, 123.6, 129.3, 131.1, 134.1, 135.6, 144.4, 148.5, 149.6, 152.8, 153.3, 156.6; MS m/z (\%) $344\left(\mathrm{M}^{+}\right)$. Anal. Calcd for $\mathrm{C}_{18} \mathrm{H}_{9} \mathrm{ClN}_{6}: \mathrm{C}, 62.71 ; \mathrm{H}$, $2.63 ; \mathrm{N}, 24.38$. Found: $\mathrm{C}, 62.46 ; \mathrm{H}, 2.44 ; \mathrm{N}, 24.28 \%$.

9-Amino-7-( $p$-tolyl)imidazo[1,2-a:5,4-b']dipyridine-6,8-dicarbonitrile (12c). Pale brown crystals (282 $\mathrm{mg}$, 87\%); $\mathrm{mp}>300^{\circ} \mathrm{C}$; IR ( $\left.\mathrm{KBr}\right) v 3456,3317,2214 \mathrm{~cm}^{-1}$; ${ }^{1} \mathrm{H}$ NMR $\left(400 \mathrm{MHz}, \mathrm{DMSO}-d_{6}\right) \delta 2.44\left(\mathrm{~s}, 3 \mathrm{H}, \mathrm{CH}_{3}\right), 7.41-$ $7.52(\mathrm{~m}, 5 \mathrm{H}, \mathrm{ArH}$ \& pyridine-H), 8.68-8.69 (m, $1 \mathrm{H}$, pyridine- $\mathrm{H}), 8.82$ (br. $\left.\mathrm{s}, 2 \mathrm{H}, \mathrm{NH}_{2}\right), 8.99-9.02$ (m, $1 \mathrm{H}$, pyridine$H) ;{ }^{13} \mathrm{C}$ NMR $\left(100 \mathrm{MHz}\right.$, DMSO- $\left.d_{6}\right) \delta 21.4,79.0,116.2,116.4,117.1,121.9,123.5,129.1,129.7,132.3,140.5$, 
148.3, 149.9, 153.0, 154.6, 156.7; MS m/z (\%) $324\left(\mathrm{M}^{+}\right)$. Anal. Calcd for $\mathrm{C}_{19} \mathrm{H}_{12} \mathrm{~N}_{6}$ : C, 70.36; $\mathrm{H}, 3.73 ; \mathrm{N}, 25.91$. Found: $\mathrm{C}, 70.15 ; \mathrm{H}, 3.55 ; \mathrm{N}, 25.79 \%$.

9-Amino-7-(4-methoxyphenyl)imidazo[1,2-a:5,4-b']dipyridine-6,8-dicarbonitrile (12d). Pale brown crystals (309 mg, 91\%); mp > $300{ }^{\circ} \mathrm{C}$; IR (KBr) v 3456, 3294, $2214 \mathrm{~cm}^{-1} ;{ }^{1} \mathrm{H}$ NMR (400 MHz, DMSO-d 6$) \delta 3.88(\mathrm{~s}, 3 \mathrm{H}$, $\left.\mathrm{OCH}_{3}\right), 7.17(\mathrm{~d}, 2 \mathrm{H}, \mathrm{ArH}, J 8.8 \mathrm{~Hz}), 7.42-7.45(\mathrm{~m}, 1 \mathrm{H}$, pyridine-H), $7.58(\mathrm{~d}, 2 \mathrm{H}, \mathrm{ArH}, J 8.4 \mathrm{~Hz}), 8.69-8.70(\mathrm{~m}, 1 \mathrm{H}$, pyridine-H), 8.81 (br. $\left.\mathrm{s}, 2 \mathrm{H}, \mathrm{NH}_{2}\right), 8.99-9.01\left(\mathrm{~m}, 1 \mathrm{H}\right.$, pyridine-H); ${ }^{13} \mathrm{C} \mathrm{NMR}\left(100 \mathrm{MHz}, \mathrm{DMSO}-d_{6}\right) \delta 55.7,79.0$, $114.5,116.2$, 116.4, 117.1, 121.8, 123.6, 127.1, 130.9, 148.0, 149.9, 152.9, 154.3, 156.7, 161.2; MS m/z (\%) 340 $\left(\mathrm{M}^{+}\right)$. Anal. Calcd for $\mathrm{C}_{19} \mathrm{H}_{12} \mathrm{~N}_{6} \mathrm{O}: \mathrm{C}, 67.05 ; \mathrm{H}, 3.55 ; \mathrm{N}, 24.69$. Found: $\mathrm{C}, 66.89 ; \mathrm{H}, 3.32 ; \mathrm{N}, 24.50 \%$.

9-Amino-7-(benzo[d][1,3]dioxol-5-yl)imidazo[1,2-a:5,4-b']dipyridine-6,8-dicarbonitrile (12e). Brown crystals (315 mg, 89\%); mp > $300{ }^{\circ} \mathrm{C}$; IR (KBr) v 3457, 3284, $2214 \mathrm{~cm}^{-1} ;{ }^{1} \mathrm{H}$ NMR (400 MHz, DMSO-d6) $\delta 6.19(\mathrm{~s}, 2 \mathrm{H}$, $\left.\mathrm{OCH}_{2} \mathrm{O}\right), 7.10-7.21(\mathrm{~m}, 3 \mathrm{H}, \mathrm{ArH}), 7.41-7.44(\mathrm{~m}, 1 \mathrm{H}$, pyridine- $\mathrm{H}), 8.68-8.69(\mathrm{~m}, 1 \mathrm{H}$, pyridine-H), 8.83 (br. $\mathrm{s}, 2 \mathrm{H}$, $\left.\mathrm{NH}_{2}\right)$, 8.98-9.01 (m, $1 \mathrm{H}$, pyridine-H); ${ }^{13} \mathrm{C}$ NMR (100 MHz, DMSO-d $) \delta 78.9,102.3,109.0,109.5,116.1,116.4$, $117.1,121.8,123.5,123.7,128.6,147.7,148.4,149.3,149.8,152.8,154.1,156.7 ; \mathrm{MS} m / z$ (\%) 354 (M+). Anal. Calcd for $\mathrm{C}_{19} \mathrm{H}_{10} \mathrm{~N}_{6} \mathrm{O}_{2}: \mathrm{C}, 64.41 ; \mathrm{H}, 2.84 ; \mathrm{N}, 23.72$. Found: $\mathrm{C}, 64.25 ; \mathrm{H}, 2.64 ; \mathrm{N}, 23.58 \%$.

9-Amino-7-(1,3-diphenyl-1H-pyrazol-4-yl)imidazo[1,2-a:5,4- $b^{\prime}$ ]dipyridine-6,8-dicarbonitrile (22a). Yellow crystals (366 mg, 81\%); mp > $300{ }^{\circ} \mathrm{C}$; IR (KBr) v 3448, 3047, $2206 \mathrm{~cm}^{-1} ;{ }^{1} \mathrm{H}$ NMR $\left(400 \mathrm{MHz}\right.$, DMSO- $\left.d_{6}\right) \delta 7.26-$ $8.38\left(\mathrm{~m}, 15 \mathrm{H}, \mathrm{ArH}, \mathrm{NH}_{2}\right.$ \& pyridine-H), 9.27 (s, 1H, pyrazole-5-H); MS m/z (\%) $452\left(\mathrm{M}^{+}\right.$). Anal. Calcd for $\mathrm{C}_{27} \mathrm{H}_{16} \mathrm{~N}_{8}$ : C, $71.67 ; H, 3.56 ; N, 24.76$. Found: $C, 71.39 ; H, 3.45 ; N, 24.57 \%$.

9-Amino-7-[1-phenyl-3-(thien-2-yl)-1H-pyrazol-4-yl]imidazo[1,2-a:5,4-b']dipyridine-6,8-dicarbonitrile (22b). Brown crystals (325 mg, 71\%); mp > $300{ }^{\circ} \mathrm{C}$; IR (KBr) v 3535, 3332, $2214 \mathrm{~cm}^{-1} ;{ }^{1} \mathrm{H}$ NMR $\left(400 \mathrm{MHz}, \mathrm{DMSO}-d_{6}\right) \delta$ 6.98-9.12 (m, 13H, ArH, NH 2 , thiophene-H \& pyridine-H), 9.25 (s, $1 \mathrm{H}$, pyrazole-H); MS m/z (\%) 458 ( $\mathrm{M}^{+}$). Anal. Calcd for $\mathrm{C}_{25} \mathrm{H}_{14} \mathrm{~N}_{8} \mathrm{~S}: \mathrm{C}, 65.49 ; \mathrm{H}, 3.08 ; \mathrm{N}, 24.44 ; \mathrm{S}, 6.99$. Found: C, 65.39; H, 2.95; N, 24.23; S, 6.76\%.

\section{Synthesis of 2-(3H-imidazo[4,5-b]pyrid-2-yl)-3-phenylacrylonitrile (20)}

To a mixture of benzaldehyde (18) (106 mg, $1 \mathrm{mmol}$ ) and 2-(3H-imidazo[4,5-b]pyrid-2-yl)acetonitrile (10) (1 $\mathrm{mmol}, 110 \mathrm{mg})$ in absolute $\mathrm{EtOH}(15 \mathrm{~mL})$ was added piperidine $(1 \mathrm{mmol}, 110 \mu \mathrm{L})$, and the mixture was heated at reflux for $3 \mathrm{~h}$. The crude solid was isolated and recrystallized from DMF/EtOH (25:75) to give 20 as brown crystals, $234 \mathrm{mg}$ (95\%); mp 260-262 ${ }^{\circ} \mathrm{C}$; IR (KBr) v 3435, 3055, 2214, cm ${ }^{-1}$; ${ }^{1} \mathrm{H}$ NMR $\left(400 \mathrm{MHz}, \mathrm{DMSO}-d_{6}\right) \delta 7.30$ (dd, $1 \mathrm{H}$, pyridine-3-H, $\left.J_{1} 8.0 \mathrm{~Hz}, J_{2} 4.8 \mathrm{~Hz}\right), 7.61-8.41(\mathrm{~m}, 7 \mathrm{H}, \mathrm{ArH}$, pyridine-2-H \& pyridine-4-H), $8.44(\mathrm{~s}, 1 \mathrm{H}$, $=\mathrm{CH}-\mathrm{Ph}), 13.98(\mathrm{~s}, 1 \mathrm{H}, \mathrm{NH})$; MS m/z (\%) $246\left(\mathrm{M}^{+}\right)$. Anal. Calcd for $\mathrm{C}_{15} \mathrm{H}_{10} \mathrm{~N}_{4}: \mathrm{C}, 73.16 ; \mathrm{H}, 4.09 ; \mathrm{N}, 22.75$. Found: C, 72.93; $\mathrm{H}, 3.97 ; \mathrm{N}, 22.55 \%$.

\section{General procedure for the synthesis of bis(2-(3H-imidazo[4,5-b]pyrid-2-yl)acrylonitrile) derivatives 25a-d}

To a mixture of appropriate bis(arylidenemalononitrile) 23a-d (1 mmole) and 2-(3H-imidazo[4,5-b]pyrid-2yl)acetonitrile (10) (2 mmol, $316 \mathrm{mg}$ ) in absolute $\mathrm{EtOH}(15 \mathrm{~mL}$ ) was added piperidine ( $2 \mathrm{mmol}, 110 \mu \mathrm{L})$, and the mixture was heated at reflux for $2 \mathrm{~h}$. The crude solid was isolated and recrystallized from DMF/EtOH (25:75) to give $25 a-d$, respectively.

2,2'-\{3,3'-[Ethane-1,2-diylbis(oxy)]bis(2,1-phenylene)\}bis[2-(3H-imidazo[4,5-b]pyrid-2-yl)acrylonitrile] (25a). Yellow crystals (478 mg, 87\%); mp 259-262 ${ }^{\circ} \mathrm{C}$; IR (KBr) v 3433, 3047, 2970, 2214, $1249 \mathrm{~cm}^{-1} ;{ }^{1} \mathrm{H}$ NMR (400 $\left.\mathrm{MHz}, \mathrm{DMSO}-d_{6}\right) \delta 4.63\left(\mathrm{~s}, 4 \mathrm{H}, \mathrm{OCH}_{2}\right), 7.06-8.38(\mathrm{~m}, 14 \mathrm{H}, \mathrm{ArH}$ \& pyridine-H), $8.59(\mathrm{~s}, 2 \mathrm{H}, 2 \mathrm{CH}), 13.63(\mathrm{br} . \mathrm{s}, 2 \mathrm{H}$, $\mathrm{NH}) ;{ }^{13} \mathrm{C}$ NMR $\left(100 \mathrm{MHz}\right.$, DMSO- $\left.d_{6}\right) \delta 68.1,103.4,104.5,113.8,114.6,116.3,119.0,121.6,122.3,125.0,128.9$, 133.9, 142.4, 145.1, 149.6, 157.8; MS m/z (\%) $550\left(\mathrm{M}^{+}\right)$. Anal. Calcd for $\mathrm{C}_{32} \mathrm{H}_{22} \mathrm{~N}_{8} \mathrm{O}_{2}: \mathrm{C}, 69.81 ; \mathrm{H}, 4.03 ; \mathrm{N}, 20.35$. Found: C, 69.55; H, 3.90; N, 20.18\%.

\section{2,2'-\{3,3'-[Propane-1,3-diylbis(oxy)]bis(2,1-phenylene)\}bis[2-(3H-imidazo[4,5-b]pyrid-2-yl)acrylonitrile]}

(25b). Pale yellow crystals (508 mg, 90\%); mp 268-270 ${ }^{\circ} \mathrm{C}$; IR (KBr) v 3417, 3055, 2954, 2214, $1249 \mathrm{~cm}^{-1} ;{ }^{1} \mathrm{H}$ NMR $\left(400 \mathrm{MHz}, \mathrm{DMSO}-d_{6}\right) \delta 2.39$ (br. $\left.\mathrm{s}, 2 \mathrm{H}, \mathrm{CH}_{2}\right), 4.38\left(\mathrm{t}, 4 \mathrm{H}, \mathrm{OCH}_{2}, J 6.4 \mathrm{~Hz}\right), 7.07-8.40(\mathrm{~m}, 14 \mathrm{H}, \mathrm{ArH} \&$ 
pyridine-H), 8.62 (s, 2H, 2CH), 13.34 (br. s, $2 \mathrm{H}, 2 \mathrm{NH}$ ); $\mathrm{MS} \mathrm{m} / z$ (\%) $564\left(\mathrm{M}^{+}\right.$). Anal. Calcd for $\mathrm{C}_{33} \mathrm{H}_{24} \mathrm{~N}_{8} \mathrm{O}_{2}: \mathrm{C}_{1} 70.20$; $H, 4.28 ; N, 19.85$. Found: C, 69.92; $H, 4.10 ; N, 19.64 \%$.

\section{2,2'-\{3,3'-[Propane-1,3-diylbis(oxy)]bis(4,1-phenylene)\}bis[2-(3H-imidazo[4,5-b]pyrid-2-yl)acrylonitrile]}

(25c). Yellow crystals (468 mg, 83\%); mp 272-274 ${ }^{\circ} \mathrm{C}$; IR (KBr) v 3464, 3047, 2954, 2214, $1257 \mathrm{~cm}^{-1} ;{ }^{1} \mathrm{H} \mathrm{NMR}$ $\left(400 \mathrm{MHz}, \mathrm{DMSO}-d_{6}\right) \delta$ 2.25-2.33 (m, 2H, CH$), 4.30\left(\mathrm{t}, 4 \mathrm{H}, \mathrm{OCH}_{2}, J 6.0 \mathrm{~Hz}\right), 7.21-8.38(\mathrm{~m}, 14 \mathrm{H}$, ArH \& pyridine$\mathrm{H}), 8.38$ (s, 2H, 2CH), 12.38 (br. s, $2 \mathrm{H}, 2 \mathrm{NH}) ;{ }^{13} \mathrm{C}$ NMR (100 MHz, DMSO-d 6 ) $\delta 28.8,65.1,99.3,115.5,116.0$, $116.8,119.0,125.6,132.3,132.6,145.0,146.8,150.7,162.0 ; \mathrm{MS} m / z$ (\%) $564\left(\mathrm{M}^{+}\right)$. Anal. Calcd for $\mathrm{C}_{33} \mathrm{H}_{24} \mathrm{~N}_{8} \mathrm{O}_{2}$ : C, 70.20; H, 4.28; N, 19.85. Found: C, 70.04; H, 4.09; N, 19.74\%.

2,2'-\{3,3'-[Butane-1,4-diylbis(oxy)]bis(4,1-phenylene)\}bis[2-(3H-imidazo[4,5-b]pyrid-2-yl)acrylonitrile] (25d). Yellow crystals (543 mg, 94\%); mp 267-270 ${ }^{\circ} \mathrm{C}$; IR (KBr) v 3446, 3047, 2954, 2214, $1257 \mathrm{~cm}^{-1} ;{ }^{1} \mathrm{H} \mathrm{NMR}(400$ $\left.\mathrm{MHz}, \mathrm{DMSO}-d_{6}\right) \delta 1.93$ (br. s, $4 \mathrm{H}, 2 \mathrm{CH}_{2}$ ), 3.4 (br. s, 2H, 2NH); 4.18 (br. s, 4H, 2CH $), 7.10-8.37$ (m, $14 \mathrm{H}, \mathrm{ArH} \&$ pyridine-H), $8.37(\mathrm{~s}, 2 \mathrm{H}, 2 \mathrm{CH}), \mathrm{MS} m / z(\%) 578\left(\mathrm{M}^{+}\right)$. Anal. Calcd for $\mathrm{C}_{34} \mathrm{H}_{26} \mathrm{~N}_{8} \mathrm{O}_{2}$ : C, 70.58; $\mathrm{H}, 4.53 ; \mathrm{N}, 19.37$. Found: C, 70.44; H, 4.30; N, 19.22\%.

\section{Computational Details}

Due to the absence of single crystal X-ray structure analysis and to attain the molecular conformation of compounds 10, 11 and 12, energy minimization analyses were done by means of Gaussian-09W software package. ${ }^{39}$ The ground state geometrical structure of the three compounds were optimized using DFT method ${ }^{40}$ with the B3LYP exchange correlation functional approach. ${ }^{41}$ The basis set $6-311 G^{* *}$ was applied for $\mathrm{C}, \mathrm{H}$ and $\mathrm{N}$ atoms. ${ }^{42}$ Without any symmetry constraints, the geometry of the investigated systems was totally optimized in gas-phase. Gauss View 5 software ${ }^{43}$ was used to create figures of molecular orbitals (MOs). The quantum chemical parameters of the studied compounds are gained from calculations as energies of the lowest unoccupied molecular orbital ( $\left.E_{\text {LUMO }}\right)$, the highest occupied molecular orbital ( $E_{\text {HOMO }}$ ), HOMO-LUMO energy gap, $E_{\mathrm{g}}$, absolute electronegativities, $\chi$, chemical potentials, $\pi$, absolute hardness, $\eta$, absolute softness, $\sigma$, global electrophilicity, $\omega$, global softness, $S$, and additional electronic charge, $\Delta N_{\text {max. }}$. These parameters are calculated using the following equations; ${ }^{44} E_{\mathrm{g}}=E_{\mathrm{LUMO}}-E_{\mathrm{HOMO}}, \chi=-E_{\mathrm{HOMO}}+E_{\mathrm{LUMO}} / 2, \eta=E_{\mathrm{LUMO}}-E_{\mathrm{HOMO}} / 2, \sigma$ $=1 / \eta, \pi=-\chi, S=1 / 2 \eta, \omega=\pi^{2} / 2 \eta$ and $\Delta N_{\text {max. }}=-\pi / \eta$. The spin density difference map calculations were also achieved to clarify their optical properties. Natural bond orbital (NBO) calculations were done ${ }^{45}$ with the NBO code contained in Gaussian 09 to understand different second order interaction between the filled orbital of one subsystem and empty orbital of another subsystem which is the calculate of the molecular delocalization or hyperconjugation. The total static dipole moment $(\mu)$, the mean polarizability $\langle\alpha\rangle$, the anisotropy of the polarizability, $\Delta \alpha$ and the mean first-order hyperpolarizability, $\langle\beta\rangle$ using the $x, y, z$ components were calculated by using the following equations at B3LYP/ GENECP level of theory: ${ }^{46}$

$$
\begin{gathered}
\mu=\left(\mu^{2} x+\mu^{2} y+\mu^{2}\right)^{1 / 2}, \\
\langle\alpha\rangle=1 / 3\left(\alpha_{x x}+\alpha_{y y}+\alpha_{z z}\right) \\
\Delta \alpha=\left(\left(\alpha_{x x}-\alpha_{y y}\right)^{2}+\left(\alpha_{y y}-\alpha_{z z}\right)^{2}+\left(\alpha_{z z}-\alpha_{x x}\right)^{2} / 2\right)^{1 / 2}, \\
\langle\beta\rangle=\left(\beta^{2}{ }_{x}+\beta^{2}{ }_{y}+\beta^{2}{ }^{2}\right)^{1 / 2}
\end{gathered}
$$

where

$$
\begin{aligned}
& \beta_{x}=\beta_{x x x}+\beta_{x y y}+\beta_{x z z} \\
& \beta_{y}=\beta_{y y y}+\beta_{x x y}+\beta_{y z z} \\
& \beta_{z}=\beta_{z z z}+\beta_{x x z}+\beta_{y y z .}
\end{aligned}
$$




\section{Supplementary Material}

${ }^{1} \mathrm{H}$ and ${ }^{13} \mathrm{C}$ NMR spectra for compounds $12 \mathrm{a}-\mathrm{e} ; 20 ; \mathbf{2 2 a}, \mathbf{b}$ and $\mathbf{2 5 a - d}$ and the tables and figures for the calculation section can be found via the "Supplementary Content" section of this article's webpage.

\section{References}

1. Ghanem, N. M.; Farouk, F.; George, R. F.; Abbas, S. E. S.; El-Badry, O. M. Bioorg. Chem. 2018, 80, 565. https://doi.org/10.1016/j.bioorg.2018.07.006

2. Anaflous, A.; Benchat, N.; Mimouni, M.; Abouricha, S.; Ben-Hadda, T.; El-Bali, B.; Hakkou, A.; Hacht, B. Lett. Drug Des. Discov. 2005, 1, 224.

https://doi.org/10.2174/1570180043398885

3. Marie Kirwen, E.; Batra, T.; Karthikeyan, C.; Deora, G. S.; Rathore, V.; Mulakayala, C.; Mulakayala, N.; Nusbaum, A. C.; Chen, J.; Amawi, H.; et al. Acta Pharm. Sin. B 2017, 7, 73. https://doi.org/10.1016/j.apsb.2016.05.003

4. Hartwich, A.; Zdzienicka, N.; Schols, D.; Andrei, G.; Snoeck, R.; Głowacka, I. E. Nucleosides, Nucleotides Nucleic Acids 2020, 39, 542.

https://doi.org/10.1080/15257770.2019.1669046

5. Cundy, D. J.; Holan, G.; Otaegui, M.; Simpson, G. W. Bioorg. Med. Chem. Lett. 1997, 7, 669. https://doi.org/10.1016/S0960-894X(97)00082-6

6. Katritzky, A. R.; Tymoshenko, D. O.; Monteux, D.; Vvedensky, V.; Nikonov, G.; Cooper, C. B.; Deshpande, M. J. Org. Chem. 2000, 65, 8059.

https://doi.org/10.1021/jo000946r

7. Li, Y.; Huang, J. H.; Wang, J. L.; Song, G. T.; Tang, D. Y.; Yao, F.; Lin, H. K.; Yan, W.; Li, H. Y.; Xu, Z. G.; et al. J. Org. Chem. 2019, 84, 12632. https://doi.org/10.1021/acs.joc.9b01385

8. Musiu, S.; Leyssen, P.; Froeyen, M.; Chezal, J. M.; Neyts, J.; Paeshuyse, J. Antiviral Res. 2016, 129, 99. https://doi.org/10.1016/j.antiviral.2016.03.007

9. Tokoroyama, T. Eur. J. Org. Chem. 2010, 2010, 2009. https://doi.org/10.1002/ejoc.200901130

10. Reyes, E.; Uria, U.; Vicario, J. L.; Carrillo, L. The Catalytic, Enantioselective Michael Reaction; John Wiley \& Sons, Inc.: Hoboken, NJ, USA, 2016. https://doi.org/10.1002/0471264180.or090.01

11. Sapale, S. R.; Borade, N. A. Eur. J. Mol. Clin. Med. 2020, 7, 4529.

12. Jadhav, S. D.; Ramasami, P.; Sekar, N. Phys. Sci. Rev. 2019, 4, 32. doi. org/10.1515/psr . https://doi.org/10.1515/psr-2018-0032

13. Nagarajan, N.; Velmurugan, G.; Prakash, A.; Shakti, N.; Katiyar, M.; Venuvanalingam, P.; Renganathan, R. Chem. Asian J. 2014, 9, 294.

https://doi.org/10.1002/asia.201301061

14. Leopoldo, M.; Lacivita, E.; Passafiume, E.; Contino, M.; Colabufo, N. A.; Berardi, F.; Perrone, R. J. Med. Chem. 2007, 50, 5043. https://doi.org/10.1021/jm070721

15. Abdelmoniem, A. M.; Ghozlan, S. A. S.; Abdelmoniem, D. M.; Elwahy, A. H. M.; Abdelhamid, I. A. J. 
Heterocycl. Chem. 2017, 54, 2844.

https://doi.org/10.1002/jhet.2890

16. Abdelhamid, I. A.; Darwish, E. S.; Nasra, M. A.; Abdel-Gallil, F. M.; Fleita, D. H. Synthesis 2010, 1107. https://doi.org/10.1055/s-0029-1219235

17. Abdella, A. M.; Mohamed, M. F.; Mohamed, A. F.; Elwahy, A. H. M.; Abdelhamid, I. A. J. Heterocycl. Chem. 2018, 55, 498.

https://doi.org/10.1002/jhet.3072

18. Elnagdi, M. H.; Al-Awadi, N. A.; Abdelhamid, I. A. Adv. Heterocycl. Chem. 2009, 97, 1. https://doi.org/10.1016/S0065-2725(08)00201-8

19. Salem, M. E.; Darweesh, A. F.; Farag, A. M.; Elwahy, A. H. M. Tetrahedron 2016, 72, 712. https://doi.org/10.1016/j.tet.2015.12.024

20. Abd El-Fatah, N. A.; Darweesh, A. F.; Mohamed, A. A.; Abdelhamid, I. A.; Elwahy, A. H. M. Tetrahedron 2017, 73, 1436 .

https://doi.org/10.1016/j.tet.2017.01.047

21. Elwahy, A. H. M.; Ahmed, M. M.; El-sadek, M. J. Chem. Res. 2001, 2001, 175. https://doi.org/10.3184/030823401103169540

22. El-Fatah, N. A. A.; Darweesh, A. F.; Mohamed, A. A.; Abdelhamid, I. A.; Elwahy, A. H. M. Monatsh. Chem. 2017, 148, 2107.

https://doi.org/10.1007/s00706-017-2040-7

23. Sanad, S. M. H.; Kassab, R. M.; Abdelhamid, I. A.; Elwahy, A. H. M. Heterocycles 2016, $92,910$. https://doi.org/10.3987/COM-16-13441

24. Abdelmoniem, A. M.; Salaheldin, T. A.; Abdelhamid, I. A.; Elwahy, A. H. M. J. Heterocycl. Chem. 2017, 54, 2670.

https://doi.org/10.1002/jhet.2867

25. Diab, H. M.; Abdelhamid, I. A.; Elwahy, A. H. M. Synlett 2018, 29, 1627. https://doi.org/10.1055/s-0037-1609967

26. Sroor, F. M.; Aboelenin, M. M.; Mahrous, K. F.; Mahmoud, K.; Elwahy, A. H. M.; Abdelhamid, I. A. Arch. Pharm. (Weinheim). 2020, 353, 2000069.

https://doi.org/10.1002/ardp.202000069

27. Takeda, K.; Shudo, K.; Okamoto, T.; Kosuge, T. Chem. Pharm. Bull. (Tokyo). 1978, 26, 2924. https://doi.org/10.1248/cpb.26.2924

28. Desbois, N.; Chezal, J. M.; Fauvelle, F.; Debouzy, J. C.; Lartigue, C.; Gueiffier, A.; Blache, Y.; Moreau, E.; Madelmont, J. C.; Chavignon, O.; et al. Heterocycles 2005, 65, 1121.

https://doi.org/10.3987/COM-05-10354

29. Zhang, K.; El Bouakher, A.; Levaique, H.; Bignon, J.; Retailleau, P.; Alami, M.; HAMZE, A. Adv. Synth. Catal. 2020, 362, 3243.

https://doi.org/10.1002/adsc.202000553

30. Pan, T.; He, X.; Chen, B.; Chen, H.; Geng, G.; Luo, H.; Zhang, H.; Bai, C. Eur. J. Med. Chem. 2015, 95, 500. https://doi.org/10.1016/j.ejmech.2015.03.050

31. Dekhane, D. V.; Pawar, S. S.; Gupta, S. V.; Shingare, M. S.; Thore, S. N. Chin. Chem. Lett. 2010, $21,519$. https://doi.org/10.1016/i.cclet.2009.11.034

32. Lyons, D. M.; Huttunen, K. M.; Browne, K. A.; Ciccone, A.; Trapani, J. A.; Denny, W. A.; Spicer, J. A. Bioorg. Med. Chem. 2011, 19, 4091.

https://doi.org/10.1016/j.bmc.2011.05.013 
33. Darweesh, A. F.; Abd El-Fatah, N. A.; Abdelhamid, I. A.; Elwahy, A. H. M.; Salem, M. E. Synth. Commun. 2020, 50, 2531.

https://doi.org/10.1080/00397911.2020.1784436

34. Ghozlan, S. A. S.; Abdelmoniem, A. M.; Butenschön, H.; Abdelhamid, I. A. Tetrahedron 2015, 71, 1413. https://doi.org/10.1016/j.tet.2015.01.026

35. Lin, Y. Y.; Rajesh, N. P.; Santhana Raghavan, P.; Ramasamy, P.; Huang, Y. C. Mater. Lett. 2002, 56, 1074. https://doi.org/10.1016/S0167-577X(02)00680-8

36. Singh, K.; Okombo, J.; Brunschwig, C.; Ndubi, F.; Barnard, L.; Wilkinson, C.; Njogu, P. M.; Njoroge, M.; Laing, L.; Machado, M.; et al. J. Med. Chem. 2017, 60, 1432.

https://doi.org/10.1021/acs.jmedchem.6b01641

37. Salem, M. E.; Hosny, M.; Darweesh, A. F.; Elwahy, A. H. M. Synth. Commun. 2019, 49, 2319. https://doi.org/10.1080/00397911.2019.1620283

38. Salama, S. K.; Darweesh, A. F.; Abdelhamid, I. A.; Elwahy, A. H. M. J. Heterocycl. Chem. 2017, 54, 305. https://doi.org/10.1002/jhet.2584

39. Frisch, M. J.; Trucks, G. W.; Schlegel, H. B.; Scuseria, G. E.; Robb, M. A.; Cheeseman, J. R.; Scalmani, G.; Barone, V.; Petersson, G. A.; Nakatsuji, H.; et al. Gaussian 09, Revision A.02; 2016.

40. Becke, A. D. J. Chem. Phys. 1993, 98, 5648. https://doi.org/10.1063/1.464913

41. Lee, C.; Yang, W.; Parr, R. G. Phys. Rev. B 1988, 37, 785. https://doi.org/10.1103/PhysRevB.37.785

42. Frisch, M. J.; Pople, J. A.; Binkley, J. S. J. Chem. Phys. 1984, 80, 3265. https://doi.org/10.1063/1.447079

43. Dennington, R.; Keith, T.; Millam, J.; Shawnee, K. S. GaussView Millam. "version 5; Semichem Inc." Shawnee Mission. KS 2009.

44. El-Sonbati, A. Z.; Diab, M. A.; El-Bindary, A. A.; Morgan, S. M. Spectrochim. Acta-Part A Mol. Biomol. Spectrosc. 2014, 127, 310.

https://doi.org/10.1016/j.saa.2014.02.037

45. Chocholoušová, J.; Špirko, V.; Hobza, P. Phys. Chem. Chem. Phys. 2004, 6, 37. https://doi.org/10.1039/B314148A

46. Avci, D. Spectrochim. Acta - Part A Mol. Biomol. Spectrosc. 2011, 82, 37. https://doi.org/10.1016/j.saa.2011.06.037 